\title{
Analysis of Crack Coalescence in Concrete Using Neural Networks
}

\author{
H. Haeri, ${ }^{\mathrm{a}, 1}$ V. Sarfarazi, ${ }^{\mathrm{b}}$ and Z. Zhu ${ }^{\mathrm{c}}$ \\ a Young Researchers and Elite Club, Bafgh Branch, Islamic Azad University, Bafgh, Iran \\ b Department of Mining Engineering, Hamedan University of Technology, Hamedan, Iran \\ ${ }^{c}$ College of Architecture and Environment, Sichuan University, Chengdu, China \\ ${ }^{1}$ haerihadi@gmail.com
}

УДК 539.4

\section{Анализ слияния трещин в бетонных конструкциях с помощью нейронных сетей}

\author{
Х. Хаэри ${ }^{\mathrm{a}}$ В. Сарфарази², Ж. Жу⿰ \\ ${ }^{\text {a } И с л а м с к и и ̆ ~ у н и в е р с и т е т ~ А з а д, ~ Б а ф к, ~ И р а н ~}$ \\ ${ }^{\sigma}$ Хамаданский технологический университет, Хамадан, Иран

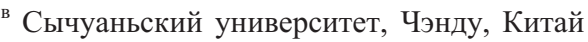

В местах разрушения бетонных конструкций часто обнаруживают макро- и микротрещины, причем на механизм их разрушения существенно влияет характер слияния трещин, выросших из исходных дефектов. Оиенка характера разрушения неустойчивых связей является одной из инженерных задач, которая учитывает ряд параметров, включая механические характеристики бетона, уровень нормальных напряжений и соотношение между площзаями поверхности дефектов и общей поверхности сдвига. Влияние этих параметров на слияние трещчн оценивается с помощьью расчетной методики нейронных сетей. Выполнено тестирование нескольких сетей с пороговыми логическими элементами и варьируемыми весовыми коэффициентами. Использовался обучаюший алгоритм обратного распространения. В качестве входных данных по слиянию трещин использовались геотехнические и геометрические параметры, а $в$ качестве выходных данных нейронная сеть выполняла оиенку типа механизма слияния трещчин (отрыва, сдвига или смешанной моды), который следовало использовать при анализе стабильности бетонных конструкиий. Выполнена верификация расчетных результатов с помощьью имеющихся экспериментальных данных.

Ключевые слова: обучающий алгоритм обратного распространения, слияние трещин, промежуток между трещинами, неустойчивая связь.

Introduction. It is well-known that the lower strength of concrete mass is mainly induced by the presence of joints. In some rare cases, it is possible that the failure in the concrete is limited to a single discontinuity. Generally, several discontinuities exist in various sizes, which constitute a combined shear surface. In this sense, the areas which are located between the neighboring discontinuities are called the bridges area (see the definition in Fig. 1) and have the greatest importance for the shear resistance of the failure surface [1-3]. Understanding of the initiation, propagation and coalescence of cracks is an important aspect in fracure mechanics. Crack propagation and coalescence processes may contribute to concrete failure in dams, foundations, and tunnels.

The pattern of coalescence between two parallel crack in both modeling materials have been done in direct shear boxes [4-8]. Also, a number of experimental studies have 
been carried out to investigate the crack initiation, propagation and coalescence in the axial or biaxial test conditions [9-25].

Two types of crack patterns have been observed in bridges by those researchers: wing cracks and secondary cracks. Wing cracks appear first; they are tensile cracks, which initiate at the tips of the joint and propagate steadily in a curvilinear path in the direction of the applied axial load. Secondary cracks appear later and are generally described as shear cracks or shear zones (Fig. 2).

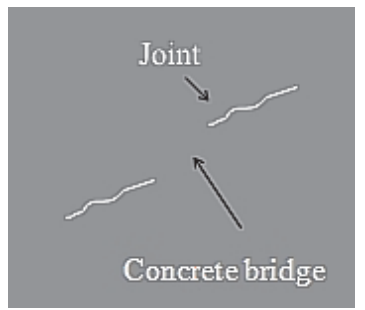

Fig. 1. Bridges in discontinuously-cracked concrete.

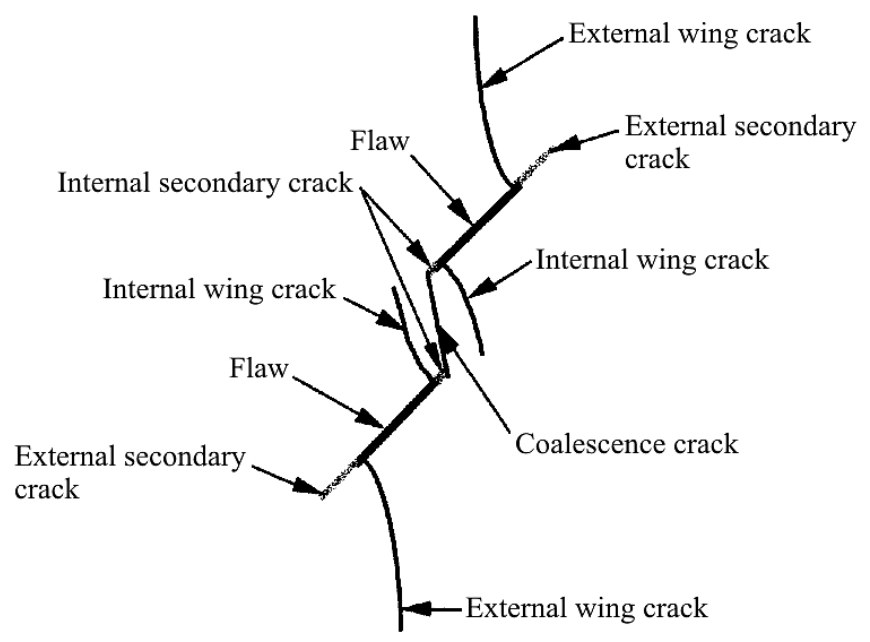

Fig. 2. Crack pattern observed in pre-cracked specimens of concrete in uniaxial compression [11].

Most of the previous studies are focused on the effect of configuration, length considering, orientation of bridge, orientation of joint segment and spacing between the joint rows on the mechanisms of crack initiation, propagation and coalescence in the bridge area; While the simultaneous effects of normal stresses, mechanical properties of model material and the ratio of joint length to bridge length on the pattern of crack coalescence is not inspected. Whereas the using of experimental tests is difficult for considering the simultaneous effects of normal stresses, mechanical properties of model material and the ratio of joint length to bridge length on crack coalescence, the neural network tool is used for this purpose.

Since their introduction, research into the area of artificial neural networks and their applications continue to captivate scientists and engineers from a variety of disciplines. This growing interest among researchers is stemming from the fact that these learning machines have an excellent performance in the issues of nonlinear function approximation, data classification, clustering and nonparametric regression or as simulations of the behavior biological neurons and pattern recognition. This paper investigates the validity of utilizing artificial neural networks in the prediction of the crack coalescence mode [i.e., 
tensile mode (type I), the shear mode (type II) and the mixed mode (type III)] that can be used for stability analysis of concrete structures.

According to $[26,27]$, all numerical modeling methods (analytical methods, basic numerical methods, finite element method, boundary element method, distinct element method, hybrid methods, extended numerical methods and fully coupled models) attempt to achieve one-to-one mechanism mapping in the model. In other words, a one-to-one mechanism occurring in reality is modeled directly such as a clear stress-strain relationship. The term 'one-to-one mapping' refers to the direct modeling of geometry and physical mechanisms, either specifically or through equivalent properties. The neural network approach is a 'non one-to-one mapping' method. In such a model, mechanism mapping is not totally direct. This model provides predicting capabilities; this is why it has been used for concrete parameter identification and prediction.

The neural network modeling approach has already been applied to a variety of subjects in geotechnical engineering [28-36]. The approach to the problem of crack coalescence from the perspective of artificial neural networks is not an easy task and requires sophisticated modeling techniques, experience, deep knowledge of engineering and a vast amount of experimental data.

In this article, the neural network and direct shear test results are used to predict the simultaneous effects of normal stresses, mechanical properties of model material and the ratio of joint length to bridge length on the pattern of crack coalescence in the nonpersistent joints. For this purpose, 450 direct shear tests have been done on the plaster of Paris specimens consisting of non-persistent joints. The uniaxial strength of material varies from 40 to $100 \mathrm{~kg} / \mathrm{cm}^{2}$ with increments of $20 \mathrm{~kg} / \mathrm{cm}^{2}$. The normal stress varies from 3 to $\sigma_{c} / 2 \mathrm{~kg} / \mathrm{cm}^{2}$ with increments of $3 \mathrm{~kg} / \mathrm{cm}^{2}$ and the jointing coefficient ( $J C$ is the ratio of joint surface to total shear surface) varies from 0.05 to 0.95 with increments of 0.1 . The shear test results are used for training, validation and testing of neural network.

1. Artificial Neural Networks (ANN). ANNs seek to simulate human brain behavior by processing data on a trial-and-error basis and learning how to avoid repeating an error the next time a similar situation occurs. Numerous advances have been made in recent years in developing intelligent systems, particularly those in which functioning is based on biological neural networks. Researchers from a wide range of disciplines have been using ANNs to find solutions to many different types of problems. Highlights among them are those involving control of complex systems when rigorous knowledge of their behavior is lacking. During the 1970s, the progress in the use of ANNs was very limited. Current models were unable to handle many problems proposed. Research was resumed after the work presented by Hopfield [37], showing the relationship between physical systems and auto associative recurrent neural networks. The multiple layer perceptron (MLP) model was proposed by Rumelhart [38] and was based on enhancing the perceptron (proposed by Rosenblatt [39]). MLP neurons are organized in layers, including data input, output, and hidden layers as shown in Fig. 3. Hidden layers are important because mathematical adjustment operations are largely performed in them. Flood and Kartan [40] stated that MLPs with at least two hidden layers provide the extra flexibility required for modeling complex systems.

During training, inputs are inserted, outputs determined and error between predicted and actual values calculated. Next, on the basis of this error, weights are adjusted starting from the output layer until the input layer is reached. This process is known as back propagation.

Common practice nowadays is the use of an independent term in the sum of the weights and inputs to each neuron in order to lend more stability to the network and particularly to enhance its generalization. A constant 1 enters each neuron as an input and is multiplied by a scalar bias. The bias is similar to a weight for this input. It is modified, as are the other weights [41]. 


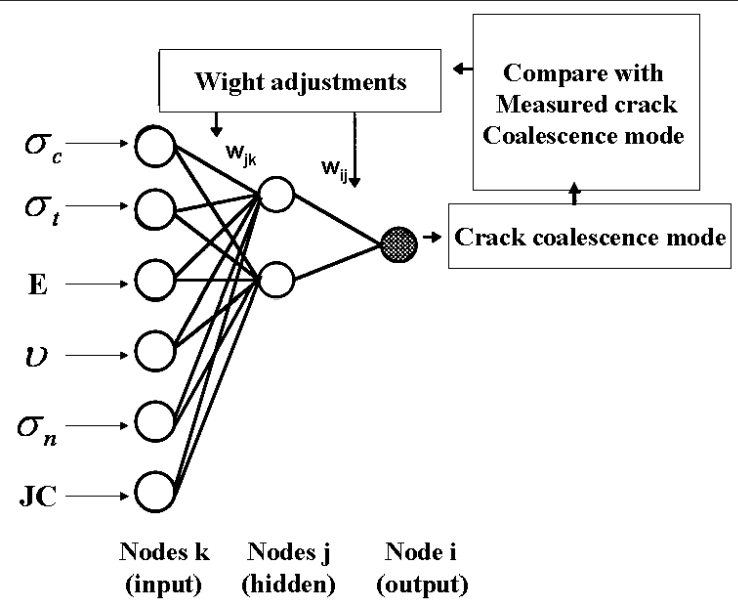

Fig. 3. Diagram showing typical MLP.

Certain tools are used to accelerate the back-propagation algorithm and reduce the incidence of local minima. One of the main points here is that much more effective results may be obtained by treating MLP network input and output data. Data normalization in order to obtain values with uniform amplitudes considerably enhances network performance. This is due to more homogeneous distribution of data as shown in Fig. 4. This procedure has been used by many researches (e.g., Flood and Kartan [40]).

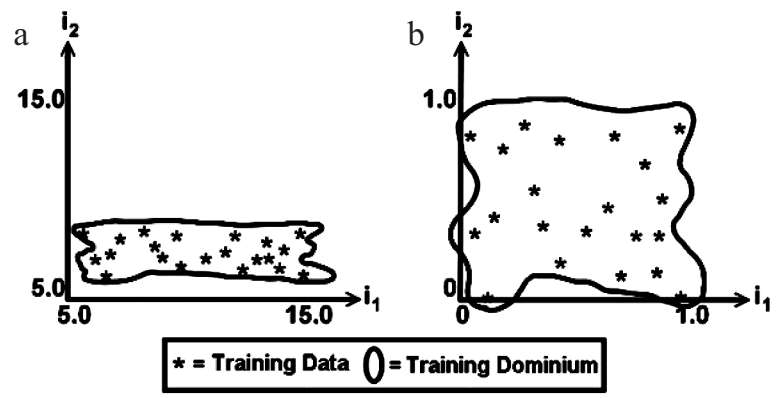

Fig. 4. Influence of data normalization on the distribution homogeneity [40].

2. Experimental Program. In order to forecast the crack coalescence mode in the case of non-persistent discontinuity under direct shearing conditions, the factors that influence fracture mode have to be determined. The material used for this investigation was cement/gypsum; the same material was used by Reyes and Einstein [10], Takeuchi [42], Shen et al. [11], Ghazvinian et al. [43], and Bobet and Einstein [12]. Totally, 450 direct shear tests have been done on the specimens consisting non-persistent joints with dimension of $15 \times 15 \times 15 \mathrm{~cm}$. Figure 5 shows the tested specimens for his study.

Four various admixtures having different mechanical properties are used for this study. The mechanical properties of the material are summarized in Table 1 .

For each type of specimen the normal stress varies from 3 to $\sigma_{c} / 2 \mathrm{~kg} / \mathrm{cm}^{2}$ with increments of $3 \mathrm{~kg} / \mathrm{cm}^{2}$ and the jointing coefficient $J C$ varies from 0.05 to 0.95 with increments of 0.1 under fixed normal stress.

The tests were performed in such a way that the normal load was applied to the specimen and then shear load was adopted. Loading is carried out using displacement control at a rate of the $0.002 \mathrm{~mm} / \mathrm{s}$. 
T a b 1 e 1

Mechanical Properties of Four Various Admixtures

\begin{tabular}{||c|c|c|c|c||}
\hline Specimens & $\begin{array}{c}\text { Uniaxial strength } \\
\sigma_{c}, \mathrm{~kg} / \mathrm{cm}^{2}\end{array}$ & $\begin{array}{c}\text { Tensile strength } \\
\sigma_{t}, \mathrm{~kg} / \mathrm{cm}^{2}\end{array}$ & $\begin{array}{c}\text { Young modulus } \\
E, \mathrm{~kg} / \mathrm{cm}^{2}\end{array}$ & $\begin{array}{c}\text { Poisson's ratio } \\
v\end{array}$ \\
\hline Type I & 40 & 5.0 & 6895 & 0.14 \\
\hline Type II & 60 & 7.5 & 10295 & 0.15 \\
\hline Type III & 80 & 9.7 & 13695 & 0.16 \\
\hline Type IV & 100 & 12.0 & 17095 & 0.17 \\
\hline
\end{tabular}

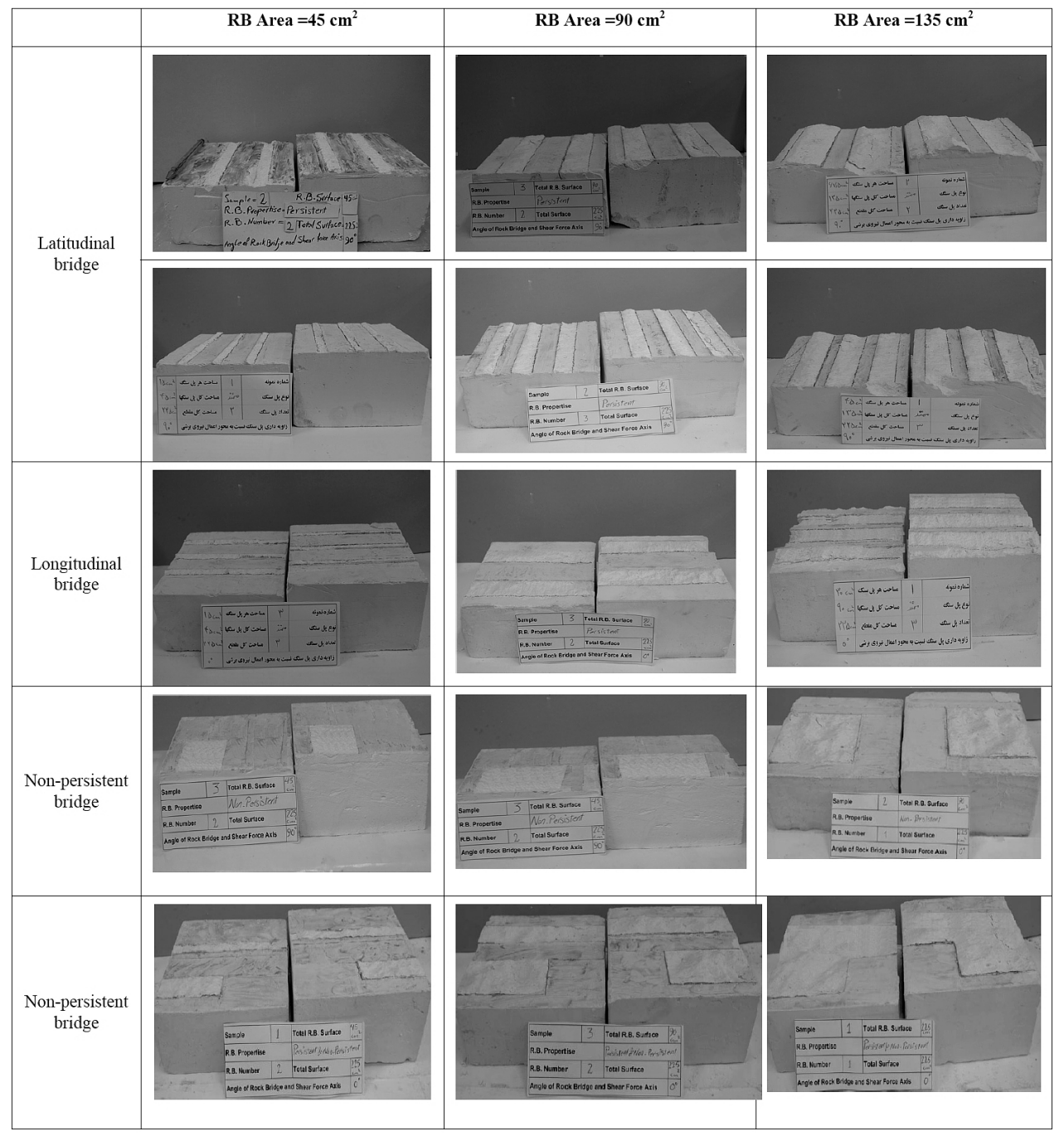

Fig. 5. Direct shear testing equipment, general set-up.

The shear experimental results showed that mechanical properties of material, normal stress and jointing coefficient $J C$ are the factors that influence crack coalescence mode.

3. Discussion on the Experimental Results. The influence of the mechanical properties of material, normal stress and the Joint Coefficient on crack coalescence mode is quite evident. In general, three main modes of crack coalescence were observed. They are 
the wing tensile mode (type I), the shear mode (type II) and the mixed mode (shear/tensile) (type III). With the increase in the jointing coefficient $J C$, the shear failure mode in the bridge changes to the tensile failure mode. Also with the increase in the normal stress, the tensile failure mode in the bridge changes to the shear failure mode. The description of crack coalescence modes and percentage amount for each compounding of $J C, \sigma_{n}$, and $\sigma_{c}$ given in Table 2. The shear test results are used for training, validation and testing of neural network.

$\mathrm{T}$ a b 1 e 2

The Amounts of Crack Coalescence Modes for Each Compounding of $J C, \sigma_{n}$, and $\sigma_{c}$

\begin{tabular}{|c|c|c|c|}
\hline$J C$ & $\sigma_{n} \leq \frac{\sigma_{c}}{6}$ & $\frac{\sigma_{c}}{6} \leq \sigma_{n} \leq \frac{\sigma_{c}}{4}$ & $\frac{\sigma_{c}}{4} \leq \sigma_{n} \leq \frac{\sigma_{c}}{2}$ \\
\hline \multirow[t]{2}{*}{0.05} & III (100\%) & III (75\%) & II $(100 \%)$ \\
\hline & & II $(25 \%)$ & \\
\hline \multirow[t]{2}{*}{0.15} & III (100\%) & III $(87.5 \%)$ & II (100\%) \\
\hline & & II $(12.5 \%)$ & \\
\hline \multirow[t]{2}{*}{0.25} & I $(28.57 \%)$ & III $(87.5 \%)$ & III (4.54\%) \\
\hline & III $(71.43 \%)$ & II $(12.5 \%)$ & II (95.46\%) \\
\hline \multirow[t]{2}{*}{0.35} & I $(50 \%)$ & III $(100 \%)$ & III (9.09\%) \\
\hline & II (50\%) & & II (90.91\%) \\
\hline \multirow[t]{2}{*}{0.45} & I $(78.5 \%)$ & III (100\%) & III $(9.09 \%)$ \\
\hline & III (21.5\%) & & II (90.91\%) \\
\hline \multirow[t]{2}{*}{0.55} & I $(100 \%)$ & I $(37.5 \%)$ & III $(13.64 \%)$ \\
\hline & & III (62.5\%) & II (86.36\%) \\
\hline \multirow[t]{3}{*}{0.65} & I $(100 \%)$ & I $(100 \%)$ & I $(22.72 \%)$ \\
\hline & & & III (4.55\%) \\
\hline & & & II $(72.73 \%)$ \\
\hline \multirow[t]{2}{*}{0.75} & I $(100 \%)$ & I $(100 \%)$ & I $(36.36 \%)$ \\
\hline & & & III $(63.64 \%)$ \\
\hline \multirow[t]{2}{*}{0.85} & I $(100 \%)$ & I $(100 \%)$ & I (54.54\%) \\
\hline & & & III $(45.45 \%)$ \\
\hline \multirow[t]{2}{*}{0.95} & I $(100 \%)$ & I $(100 \%)$ & I $(95.45 \%)$ \\
\hline & & & III (4.55\%) \\
\hline
\end{tabular}

4. ANN Architecture. The main scope of this work is to implement the ANN architecture in the problem of crack coalescence pattern prediction. A brief analysis of the results obtained through the direct shear tests described in the previous sections helps to identify the suitable input parameters to the ANN for training and then to test the ANN once it is trained. The experimental results discussed in the previous section clearly show that there exists a strong dependence of mechanical properties of material, normal stress $\left(\sigma_{n}\right)$ and the jointing coefficient on crack coalescence mode. Therefore the ANN model consists of six input parameters, i.e., uniaxial strength $\left(\sigma_{c}\right)$, tensile strength $\left(\sigma_{t}\right)$, the Young modulus $(E)$, Poisson's ratio $(v)$, normal stress $\left(\sigma_{n}\right)$, and joint coefficient $(J C)$. 
These data's are divided into training, validation, and test sets. The validation set is used to ensure that there is no overfitting in the final result. The test set provides an independent measure of how well the network can be expected to perform on data not used to train it. $20 \%$ of the data was used for the validation set and $20 \%$ was used for the test set, leaving $60 \%$ for the training set. The sets are picked randomly from the original data.

The well known feed forward neural network learning by BP algorithm written in MATLAB has been used and its ability to predict the crack coalescence mode has been studied by training and testing the ANN for various cases of inputs and comparing its performance for various input conditions.

Trying to achieve the best network's performance, several networks with different architectures were developed using all the possible variations of the back-propagation algorithms available in MATLAB v.7.0. The specifications of the artificial neural network that gave the best performance are used in this study are as follows:

The input layer data consists of six input parameters.

Number of input nodes in the input layer: 6 .

Number of output nodes in the output layer: 1.

No of hidden layers: 3 with 29, 20, and 15 nodes, respectively.

Training algorithm used: back propagation.

Transfer Function of layers: tansig.

Back propagation network training function: traingdm.

Back propagation weight/bias learning function: learngdm.

Performance function: MSE.

The learning rate was set to $l r=0.005$ and the error goal was set to $E G=4 \cdot 10^{-4}$.

The output of the neural network is the crack coalescence mode.

In this work, the crack coalescence mode is considered as discrete values 0,1 , or -1 . The values of 0,1 , or -1 are the mark of the mix mode, the shear mode or the tensile mode of failure respectively.

In Fig. 6, the simulation of the network architecture using the SIMULINK module of MATLAB v. 7.0 is presented.

5. The Network's Analysis. Plot of the training, validation, and test errors for ANN model of crack coalescence mode is given in Fig. 7 to check the progress of training. The result for the model is reasonable, since the test set errors and the validation set errors have similar characteristics, and it does not appear that any significant overfitting has occurred.

The network outputs for 62 new data of test sets and corresponding targets are also drawn as shown in Fig. 8 in order to have a better understanding about the prediction capabilities of the employed ANN model. The horizontal scale is the specimen number, whereas the vertical scale is crack coalescence mode. Solid points on this plot show the output of the neural net, whereas the hollow points represent the actual crack coalescence mode (the values of 0,1 , or -1 are the representing of the mix mode, the shear mode or the tensile mode of failure respectively). As it can be seen from Fig. 8 the network has given predicted values close to the measured ones.

Finally, in order to compare experimental and ANN model, the correlation coefficients between the respective values of observations and prediction values for crack coalescence mode based on ANN model were also calculated and found to be 0.99 for network. These outcomes and scatter plots (Fig. 9) exhibit the superior performance of ANN models with reference to regression analyses.

6. Sensitivity Analysis. Sensitivity analyses were performed varying the desired parameter and maintaining fixed values for the other parameters. The parameters to be analyzed varied between its minimum and maximum values of the dataset. The network topology used was the one that yielded the best results. Figures 10-15 show the graphs obtained from the sensitivity analyses of the following parameters: uniaxial strength of 


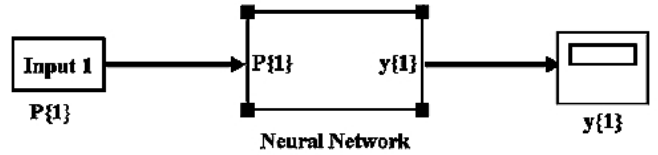

Input-Hidden-Output Layers

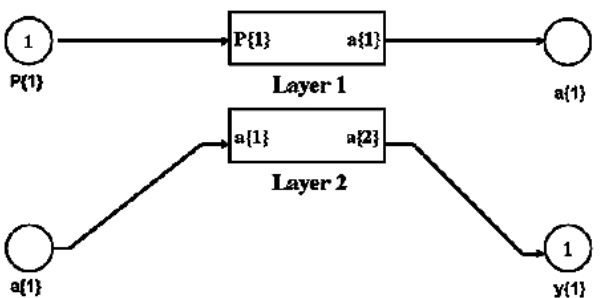

Neural network architecture: Layer1 : input, Layer2: output.

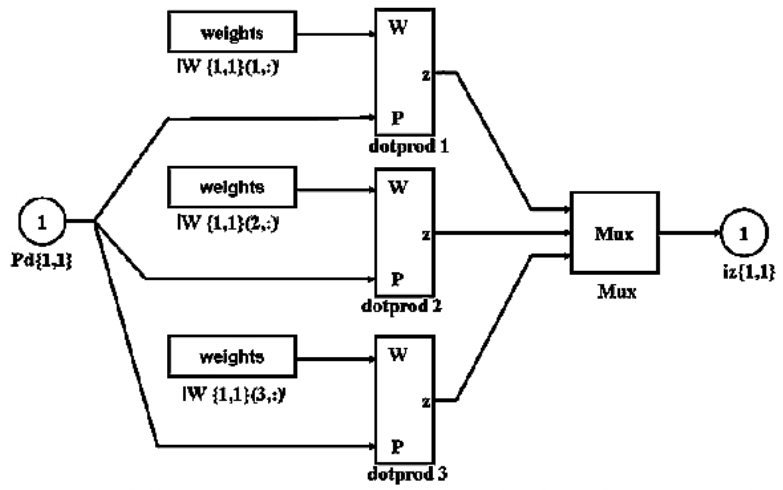

Schematic representation of: input layer and weights from the input to hidden layer.

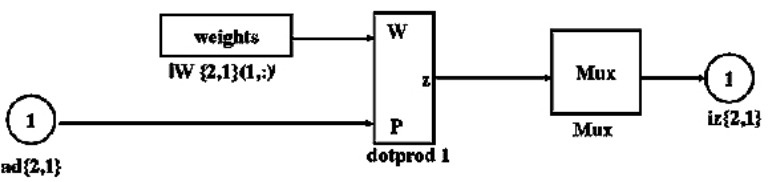

Schematic representation of: second layer and weights from the hidden to output layer.

Fig. 6. Neural network architecture visualized by SIMULINK.

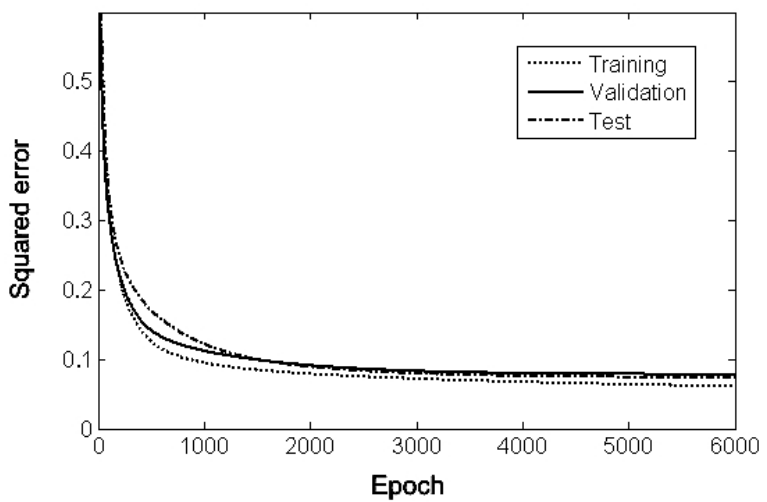

Fig. 7. Network errors vs number of iterations/epochs. 


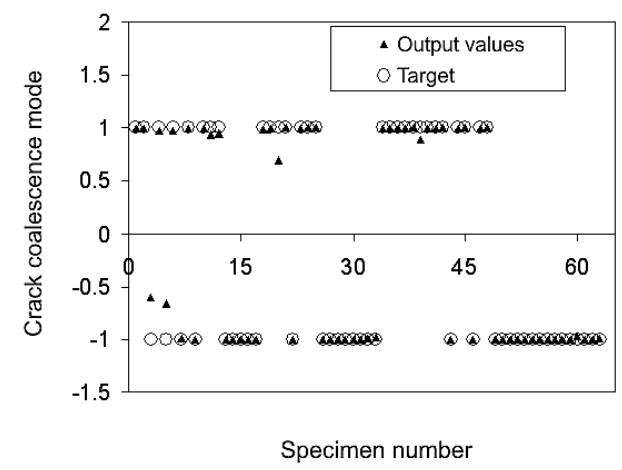

Fig. 8

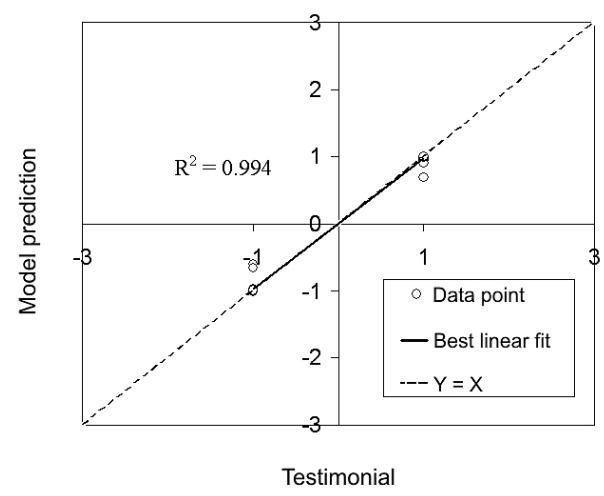

Fig. 9

Fig. 8. The network output and corresponding target for 62 new data.

Fig. 9. Scatter diagrams for crack coalescence mode.

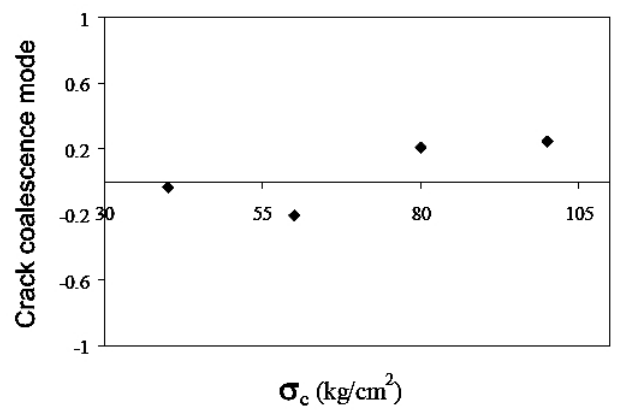

Fig. 10

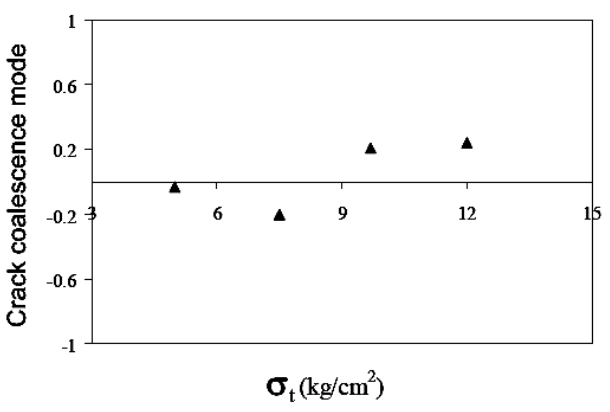

Fig. 11

Fig. 10. Sensitivity analysis - uniaxial strength $\left(\sigma_{c}\right)$.

Fig. 11. Sensitivity analysis - tensile strength $\left(\sigma_{t}\right)$.

material, tensile strength of material, the Young modulus, Poisson's ratio, normal stress, and joint coefficient. Figure 10 shows the effect of uniaxial strength of material on failure pattern of non-persistent joint with $J C=0.45$ under $9 \mathrm{~kg} / \mathrm{cm}^{2}$ of normal load. 4 equidistant points $\left(\sigma_{c}=40-100 \mathrm{~kg} / \mathrm{cm}^{2}\right.$ with increments of $\left.20 \mathrm{~kg} / \mathrm{cm}^{2}\right)$ were used to predict the crack coalescence mode.

The mix mode coalescence appears for all of the uniaxial strength values. This result shows that the crack coalescence mode is not sensitive to uniaxial strength of material in this data range.

Figure 11 shows the effect of tensile strength of material on failure pattern of nonpersistent joint with $J C=0.45$ under $9 \mathrm{~kg} / \mathrm{cm}^{2}$ of normal load. 4 equidistant points were used to predict the crack coalescence mode $\left(\sigma_{t}=5,7.5,9.7\right.$, and $\left.12 \mathrm{~kg} / \mathrm{cm}^{2}\right)$. The mix mode coalescence appears for all of the tensile strength values. These results show that the crack coalescence mode is not sensitive to tensile strength of material in this data range.

The similar results gained from Figs. 12 and 13 shows that the crack coalescence mode is not sensitive to the Young modulus and Poisson's ratio of material too.

Figure 14 portrays the results for crack coalescence mode variation with joint coefficient $J C .10$ equidistant points $(J C=0.05-0.95$ with increments of 0.1$)$ were used to predict the crack coalescence mode under follow condition: $\sigma_{n}=9 \mathrm{~kg} / \mathrm{cm}^{2}, \sigma_{c}=40 \mathrm{~kg} / \mathrm{cm}^{2}$, $\sigma_{t}=5 \mathrm{~kg} / \mathrm{cm}^{2}, E=6895 \mathrm{~kg} / \mathrm{cm}^{2}$, and Poisson's ratio $v=0.15$. 


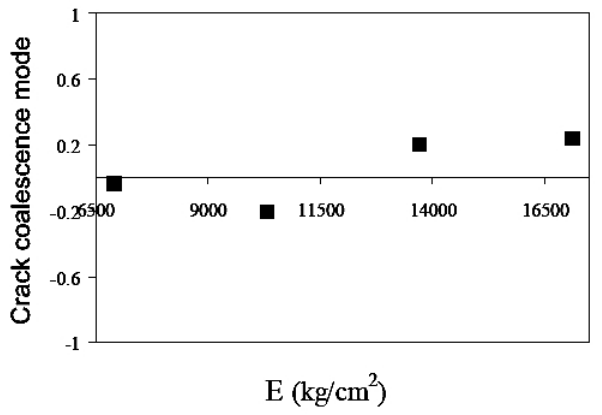

Fig. 12

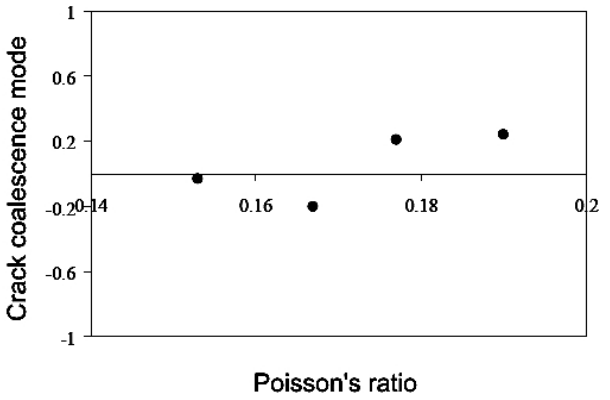

Fig. 13

Fig. 12. Sensitivity analysis - the Young modulus $(E)$.

Fig. 13. Sensitivity analysis - Poisson's ratio $(v)$.

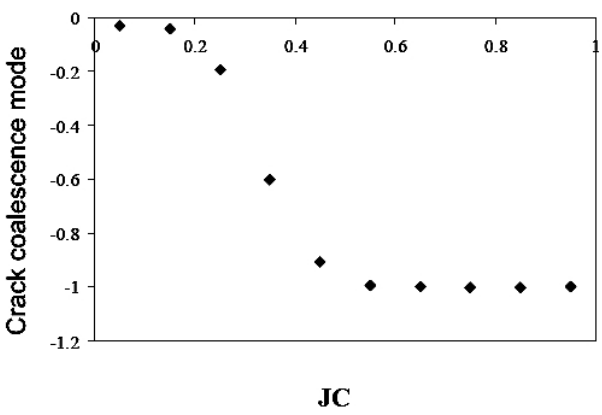

Fig. 14

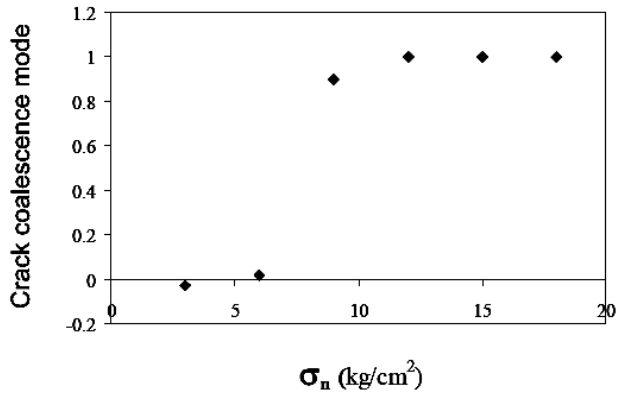

Fig. 15

Fig. 14. Sensitivity analysis - joint coefficient $(J C)$.

Fig. 15. Sensitivity analysis - normal stress $\left(\sigma_{n}\right)$.

The results show that the crack coalescence mode is sensitive to $J C$ so that increasing in $J C$ change mix mode of failure to tensile failure.

Finally, Fig. 15 shows the crack coalescence mode with respect to the normal stress $\sigma_{n} .6$ equidistant points $\left(\sigma_{n}=3-18 \mathrm{~kg} / \mathrm{cm}^{2}\right.$ with increments of $\left.3 \mathrm{~kg} / \mathrm{cm}^{2}\right)$ were used to predict the failure pattern of non-persistent joint with $J C=0.45, \sigma_{c}=40 \mathrm{~kg} / \mathrm{cm}^{2}$, $\sigma_{t}=5 \mathrm{~kg} / \mathrm{cm}^{2}, E=6895 \mathrm{~kg} / \mathrm{cm}^{2}$, and Poisson's ratio $v=0.15$. Figure 15 shows that the crack coalescence mode is sensitive to normal stress so that increasing in normal stress changes mix mode of failure to shear mode of failure (it is to be note that the values of 0 , 1 , or -1 are the represents of the mix mode, the shear mode or the tensile mode of failure, respectively).

Therefore, the analyses showed that the most influencing parameters on the crack coalescence are the joint coefficient $J C$ and normal stress $\sigma_{n}$.

Conclusions. A neural network is a good approach for engineering problems in which the mechanism is complex. Many factors influence the process and the result and current methods are from perfect. In this study, the ANN model that can be used for determining the crack coalescence mode has been developed. For this purpose, experimental results have been used. The ANN model consists of six input parameters (uniaxial strength, tensile strength, the Young modulus, Poisson's ratio, normal stress, and joint coefficient).

The best adjustment was obtained from a network topology of three hidden layers, with 29 neurons in the first layer, 20 in the second layer, and 15 neurons in the third layer. The learning rate was 0.005 . The correlation coefficients between the respective values of 
observations and prediction values for crack coalescence mode based on ANN model were calculated and found to be 0.99 for networks; thus showing a significant improvement in adjustments and results.

The sensitivity analyses were appropriate and enabled to verify the effect of certain parameters on the crack coalescence mode. A highlight here was the $J C$ and normal stress $\sigma_{n}$. The results show that these parameters have significant effects on the crack coalescence mode.

\section{Резиме}

У місцях руйнування бетонних конструкцій часто виявляють макро- і мікротріщини, при цьому на механізм їх руйнування суттєво впливає характер злиття тріщин, що виросли 3 початкових дефектів. Оцінка характера руйнування нестійких зв'язків $\epsilon$ однією з інженерних задач, яка враховує ряд параметрів, включаючи механічні характеристики бетону, рівень нормальних напружень і співвідношення між площами поверхні дефектів і загальною поверхнею зсуву. Вплив цих параметрів на злиття тріщин визначається за допомогою розрахункової методики нейронних сіток. Виконано тестування декількох сіток із пороговими логічними елементами і варійованими ваговими коефіцієнтами. Використовувався навчальний алгоритм зворотного розповсюдження. Вхідними даними по злиттю тріщин слугували геотехнічні і геометричні параметри, а вихідними - нейронна сітка, за допомогою якої оцінювався тип механізму злиття тріщин (відрив, зсув або змішана мода), який використовувався при аналізі стабільності бетонних конструкцій. Виконано верифікацію розрахункових результатів за допомогою відомих експериментальних даних.

1. E. Eberhardt, D. Stead, J. Coggan, and H. Willenberg, "An integrated numerical analysis approach to the Randa rockslide," in: Proc. of the First European Conference on Landslides, Prague (2002), pp. 355-362.

2. Y. H. Hatzor, A. A. Arzi, Y. Zaslavsky, and A. Y., Shapira, "Dynamic stability analysis of jointed rock slopes using the DDA method: King Herod's Palace, Masada, Israel," Int. J. Rock Mech. Min. Sci., 41, No. 5, 813-832 (2004).

3. Y. P. Li, L. Z. Chen, and Y. H. Wang, "Experimental research on pre-cracked marble under compression," Int. J. Solids Struct., 42, Nos. 9-10, 2505-2516 (2005).

4. E. Z. Lajtai, "Shear strength of weakness planes in rock," Int. J. Rock Mech. Min. Sci. Geomech. Abstr., 6, No. 5, 499-508, IN7-IN8, 509-515 (1969).

5. E. Z. Lajtai, "Strength of discontinuous rocks in direct shear," Géotechnique, 19, No. 2, 218-233 (1969).

6. T. Savilahti, Rock Bridges in Jointed Rock Masses - State-of-the-Art, Research Report, Tulea (1988).

7. T. Savilahti, E. Nordlund, and O. Stephansson, "Shear box testing and modelling of joint bridges," in: N. Barton and O. Stephansson (Eds.), Rock Joints (Proc. of the Int. Symp. Rock Joints, June 4-6, 1990, Loen, Norway), Balkema, Rotterdam (1990), pp. 295-300.

8. C. Li, O. Stephansson, and T. Savilahti, "Behaviour of rock joints and rock bridges in shear testing," in: N. Barton and O. Stephansson (Eds.), Rock Joints (Proc. of the Int. Symp. on Rock Joints, June 4-6, 1990, Loen, Norway), Balkema, Rotterdam (1990), pp. 259-266.

9. H. H. Einstein, D. Veneziano, G. B. Baecher, and K. J. O'Reilly, "The effect of discontinuity persistence on rock slope stability," Int. J. Rock Mech. Min. Sci. Geomech. Abstr., 20, No. 5, 227-236 (1983). 
10. O. Reyes and H. H. Einstein, Failure mechanisms of fractured rock-a fracture coalescence model, in: Proc. of the Seventh Int. Congress on Rock Mechanics (Sept. 16-20, 1991, Aachen, Germany), Vol. 1 (1991), pp. 333-340.

11. B. Shen, O. Stephansson, H. H. Einstein, and B. Ghahreman, "Coalescence of fractures under shear stress experiments," J. Geophys. Res., 6, 5975-5990 (1996).

12. A. Bobet, and H. H. Einstein, "Fracture coalescence in rock-type materials under uniaxial and biaxial compression," Int. J. Rock Mech. Min. Sci., 35, 863-888 (1998).

13. R. H. C. Wong and K. T. Chau, "Crack coalescence in rock-like material containing two cracks," Int. J. Rock Mech. Min. Sci., 35, 147-164 (1998).

14. R. H. C. Wong, K. T. Chau, C. A. Tang, and P. Lin, "Analysis of crack coalescence in rock-like materials containing three flaws - Part I: Experimental approach," Int. J. Rock Mech. Min. Sci., 38, 909-924 (2001).

15. M. Sagong and A. Bobet, "Coalescence of multiple flaws in a rock-model material in uniaxial compression," Int. J. Rock Mech. Min. Sci., 39, 229-241 (2002).

16. O. S. Mughieda and I. Khawaldeh, "Coalescence of offset rock joints under biaxial loading," Geotech. Geol. Eng., 24, 985-999 (2006).

17. H. Haeri, K. Shahriar, M. F. Marji, and P. Moarefvand, "Experimental and numerical study of crack propagation and coalescence in pre-cracked rock-like disks," Int. J. Rock Mech. Min. Sci., 67, 20-28 (2013).

18. H. Haeri, K. Shahriar, M. F. Marji, and P. Moarefvand, "On the cracks coalescence mechanism and cracks propagation paths in rock-like specimens containing pre-existing random cracks under compression," J. Central South Univ., 21, No. 6, 2404-2414 (2014).

19. H. Haeri, K. Shahriar, M. F. Marji, and P. Moarefvand, "Investigation of fracturing process of rock-like Brazilian disks containing three parallel cracks under compressive line loading," Strength Mater., 46, No. 3, 404-416 (2014).

20. H. Haeri, K. Shahriar, M. F. Marji, and P. Moarefvand, "On the HDD analysis of micro crack initiation, propagation, and coalescence in brittle substances," Arab. J. Geosci., 8, No. 5, 2841-2852 (2015).

21. H. Haeri, M. F. Marji, and K. Shahriar, "Simulating the effect of disc erosion in TBM disc cutters by a semi-infinite DDM," Arab. J. Geosci., 8, No. 6, 3915-3927 (2015).

22. H. Haeri, "Propagation mechanism of neighboring cracks in rock-like cylindrical specimens under uniaxial compression," J. Min. Sci., 51, No. 3, 487-496 (2015).

23. H. Haeri, "Simulating the crack propagation mechanism of pre-cracked concrete specimens under shear loading conditions," Strength Mater., 47, No. 4, 618-632 (2015).

24. H. Haeri, A. Khaloo, and M. F. Marji, "Experimental and numerical simulation of the microcrack coalescence mechanism in rock-like materials," Strength Mater., 47, No. 5, 740-754 (2015).

25. H. Haeri, A. Khaloo, and M. F. Marji, "Experimental and numerical analysis of Brazilian discs with multiple parallel cracks," Arab. J. Geosci., 8, No. 8, 5897- 5908 (2015).

26. L. Jing and J. A. Hudson, "Numerical methods in rock mechanics," Int. J. Rock Mech. Min. Sci., 39, 409-427 (2002).

27. L. Jing, "A review of techniques, advances and outstanding issues in numerical modeling for rock mechanics and rock engineering," Int. J. Rock Mech. Min. Sci., 40, 283-353 (2003). 
28. D. L. Millar and J. A. Hudson, "Performance monitoring of rock engineering systems utilizing neural networks," Trans. Inst. Min. Metal. A-Min. Ind., 103, A13-A16 (1994).

29. A. T. C. Goh, "Back-propagation neural networks for modelling complex systems," Artif. Intell. Eng., 9, No. 3, 143-151 (1995).

30. A. T. C. Goh, "Seismic liquefaction potential Assessed by neural networks," $J$. Geotech. Eng., 120, No. 9, 1467-1480 (1995).

31. P. Sklavounos and M. Sakellariou, "Intelligent classification of rock masses," in: G. Rzevski, R. A. Adey, and C. Tasso (Eds.), Applications of Artificial Intelligence in Engineering (Proc. of the Tenth Int. Conf. on Applications of Artificial Intelligence in Engineering, July, 1995, Udine, Italy), Computational Mechanics Publications (1995), pp. 387-393.

32. Y. M. Najjar and I. A. Basheer, "Utilising computational neural networks for evaluating the permeability of compacted clay liners," Geotech. Geol. Eng., 14, 193212 (1996).

33. S. Gangopadhyay, T. R. Gautam, A. D. Gupta, "Subsurface characterisation using artificial neural network and GIS," J. Comput. Civil Eng., 13, No 3, 153-161 (1999).

34. J. H. Deng and C. F. Lee, "Displacement back analysis for a steep slope at the three gorges project site," Int. J. Rock Mech. Min. Sci., 38, 259-268 (2001).

35. H.-C. Chang, D. C. Kopaska-Merkel, and H. C. Chen, "Identification of lithofacies using Kohonen self-organising maps," Comput. Geosci., 28, No. 2, 223-229 (2002).

36. Y. Yang and M. S. Rosenbaum, "The artificial neural network as a tool for assessing geotechnical properties," Geotech. Geol. Eng., 20, 149-168 (2001).

37. J. J. Hopfield, "Neural networks and physical systems with emergent collective properties," P. Natl. Acad. Sci. USA, 79, No. 8, 2554-2558 (1982).

38. D. E. Rumelhart, "Learning representations by back-propagating errors," Nature, 323, 533-536 (1986).

39. F. Rosenblatt, "The perceptron: a probabilistic model for information storage and organization in the brain," Psychol. Rev., 65, 386-408 (1958).

40. I. Flood and N. Kartan, "Neural networks in civil engineering. I: Principles and understanding," J. Comput. Civil Eng., 8, No. 2, 131-148 (1994).

41. S. Haykin, Neural Networks - A Comprehensive Foundation, Prentice-Hall (1994).

42. K. Takeuchi, Mixed-Mode Fracture Initiation in Granular Brittle Materials, M.S. Thesis, Massachusetts Institute of Technology, Cambridge (1991).

43. A. Ghazvinian, M. R. Nikudel, and V. Sarfarazi, "Determination of sliding path in rock slopes containing coplanar non-persistent open discontinuity," World Appl. Sci. J., 3, No. 4, 577-589 (2008). 